JPdK Volume 1 Nomor 1 Tahun 2019 Halaman 38-47

JURNAL PENDIDIKAN dan KONSELING

Research \& Learning in Faculty of Education

\title{
Peningkatan Hasil Belajar IPA dengan Pendekatan CTL (Contextual Teaching and Learning) Siswa Sekolah Dasar
}

\author{
Nurul Nofriani ${ }^{1}$, Yusnira ${ }^{2}$, Putri Hana Pebriana ${ }^{3}$ \\ Program Studi Pendidikan Guru Sekolah Dasar \\ Fakultas Ilmu Pendidikan \\ Universitas Pahlawan Tuanku Tambusai \\ Email: Nurulnofriani@gmail.com
}

\begin{abstract}
Abstrak
Penelitian ini dilatar belakangi oleh rendahnya hasil belajar IPA. Hal ini didasarkan pada jumlah siswa yang hasil belajarnya dibawah Kriteria ketuntasan minimum (KKM) yang ditetapkan sekolah yaitu 75, dari 26 orang siswa 10 orang siswa yang mendapat nilai baik atau diatas KKM, dan 16 orang siswa yang mendapat nilai dibawah KKM. Penelitian ini merupakan tindakan kelas, penelitian tindakan kelas ini bertujuan untuk mendeskripsikan peningkatan hasil belajar pada materi peristiwa alam dengan penerapan pendekatan CTL (Contextual Teaching and Learning) pada siswa kelas Va SDN 001 Salo. Penelitian ini dilaksanakan pada bulan April 2016, subjek penelitian ini adalah siswa kelas Va SDN 001 Salo yang berjumlah 26 orang siswa yang terdiri dari 12 orang siswa laki-laki dan 14 orang siswa perempuan. Teknik pengumpulan data dalam penelitian ini adalah teknik observasi, teknik dokumentasi dan teknik tes. Berdasarkan hasil penelitian dapat disimpulkan bahwa ketuntasan sebelum tindakan hanya mencapai $38,46 \%$, siklus I meningkat menjadi $73,08 \%$ dan siklus II meningkat lagi menjadi 92,31\%. Dapat disimpulkan bahwa dengan penerapan pendekatan CTL (Contextual Teaching and Learning) dapat meningkatkan hasil belajar IPA pada materi peristiwa alam pada siswa kelas Va SDN 001 Salo.
\end{abstract}

Kata kunci: Hasil Belajar, Pendekatan CTL (Contextual Teaching and Learning), IPA

\section{PENDAHULUAN}

Hayat \& Yusuf (Wisudawati, 2014: 11), konsep IPA yang disampaikan oleh guru belum banyak digunakan oleh siswa dalam memecahkan masalah yang mereka jumpai. Di Indonesia, siswa yang mempelajari IPA relatif belum mampu menggunakan pengetahuan IPA yang mereka peroleh untuk menghadapi tantangan kehidupan nyata. Hasil survey Trends in International Mathematics and Science Study (TIMSS) dari 46 negara berpartisipasi pada tahun 2003, anak
Indonesia menempati peringkat 37. Sedangkan tahun 2007, Indonesia menempati peringkat 36 dari 49 negara. Rerata skor siswa 397 jauh lebih rendah dibanding rerata internasional 500 . Permasalahan kurikulum IPA di Indonesia kurang diimplementasikan oleh kebanyakan sekolah sehingga menyebabkan kurang efektifnya proses pembelajaran, Depdiknas (Ain, 2013: 3).Sesuai dengan amanat peraturan pemerintah Nomor 19 Tahun 2005 tentang Standar Nasional Pendidikan, bahwa proses pembelajaran pada setiap satuan pendidikan dasar dan menengah 
harus interaktif, inspiratif,

menyenangkan, menantang dan memotivasi siswa untuk berpartisipasi aktif dalam pembelajaran. Oleh karna itu, pembelajaran hendaknya dapat memberikan pengalaman langsung dan bemakna kepada siswa. Pada pembelajaran IPA, pemahaman terhadap konsep-konsep pelajaran itu penting sehingga dapat memberi pengalaman langsung kepada siswa. Pemahaman terhadap konsepkonsep yang baik akan membuat siswa menempatkan konsep-konsep tersebut dalam sistem memori jangka panjang (long term memory). Pemahaman konsepkonsep yang baik semestinya akan mempermudah mereka dalam mencapai kriteria ketuntasan minimal (KKM) yang telah ditetapkan oleh sekolah. Namun dalam kenyataannya, berdasarkan hasil pengamatan dan wawancara yang dilakukan pada tanggal 26 Januari 2016 dengan guru kelas Va di Sekolah Dasar Negri 001 Salo Kecamatan Salo, fenomena yang terjadi ialah: (1) Guru lebih mendominasi dalam proses

pembelajaran, siswa belajar sebatas menerima pengetahuan dari guru sehingga siswa cenderung pasif dan siswa mulai bosan dengan materi yang disampaikan guru, (2) Siswa kurang memperhatikan guru saat menjelaskan pelajaran, disini terlihat ada siswa yang bernyanyi, bermain, berbicara dengan teman sebangku, serta mengganggu teman yang lain, (3) Komunikasi pembelajaran hanya satu arah, kurang adanya interaksi timbal balik antara guru dengan siswa, ini terlihat tidak ada siswa yang bertanya pada saat pembelajaran, (4) Kurangnya tanggung jawab dalam melaksanakan tugas yang diberikan guru karena siswa sulit memahami pelajaran, (5) Hal-hal tersebut pada akhirnya mengakibatkan rendahnya hasil belajar IPA siswa, ini ditandai dengan hasil ulangan harian siswa kelas Va pada mata pelajaran
IPA, dimana tidak semua siswa mencapai Kriteria Ketuntasan Minimal (KKM). KKM yang ditetapkan sekolah untuk mata pelajaran IPA adalah 75, namun dari 26 siswa, yang mendapat nilai di atas KKM hanya 10 siswa $(38,46 \%)$, sedangkan 16 siswa lainnya mendapat nilai dibawah KKM (61,54\%). Selain itu, data juga menunjukkan nilai rata-rata terendah 30 dan tertingggi 90 .

Agar hasil belajar IPA siswa pada materi Peristiwa Alam dapat mencapai nilai yang ditetapkan, maka guru dituntut untuk menerapkan suatu pendekatan pembelajaran yang dapat membuat siswa aktif dalam proses pembelajaran.

Oleh karenanya, peneliti memberikan satu solusi yang diharapkan nantinya dapat membantu guru dalam mengatasi masalahmasalah yang terjadi dikelas tersebut yakni dengan pendekatan CTL (Contextual Teaching and Learning) untuk mewujudkan pembelajaran yang lebih bermakna.

Ketika siswa dapat mengaitkan isi dari mata pelajaran dengan pengalaman mereka sendiri, mereka menemukan makna dan makna memberi mereka alasan untuk belajar karena ketika diminta untuk mempelajari sesuatu yang tidak bermakna, para siswa biasanya bertanya, " Mengapa saya harus mempelajari ini?" wajar sekali jika mencari makna atau maksud dari tugas sekolah yang mereka terima (Johnson, 2014: 35-91).

Menurut Howey R, Kenet (Rusman, 2014: 189) CTL (Contextual Teaching and Learning) adalah pembelajaran yang memungkinkan terjadinya proses belajar dimana siswa menggunakan pemahaman dan kemampuan akademiknya dalam berbagai konteks dalam dan luar sekolah untuk memecahkan masalah yang bersifat nyata. 
Kelebihan pembelajaran CTL (Contextual Teaching and Learning) menurut Taufik (2009: 196) yaitu: (1) Siswa membangun sendiri pengetahuannya, maka siswa tidak pernah lupa, (2) Suasana dalam proses pembelajaran menyenangkan karena menggunakan realitas kehidupan, sehingga siswa tidak bosan belajar, (3) Siswa merasa dihargai dan semakin terbuka karena setiap jawaban ada penilaiannya, (4) Memupuk kerjasama dalam kelompok, siswa dilibatkan secara aktif dalam proses pembelajaran,

(5) Siswa belajar saling menerima dan memberi pendapat melalui kerja kelompok, (6) pembelajaran terjadi diberbagai tempat.

Berdasarkan permasalahan diatas, agar tercipta proses pembelajaran yang aktif dan hasil belajar IPA siswa meningkatpeneliti mencoba mengadakan Penelitian Tindakan Kelas dengan judul: "Peningkatan Hasil Belajar IPA dengan Pendekatan CTL (Contextual Teaching and Learning) Siswa Sekolah Dasar (Penelitian Tindakan Kelas pada Materi Peristiwa Alam Siswa Kelas Va SDN 001 Salo)".

\section{METODOLOGI PENELITIAN}

Metode penelitian ini adalah Penelitian Tindakan Kelas (PTK). Penelitian Tindakan Kelas (PTK) sudah dikenal lama dalam dunia pendidikan. Penelitian Tindakan Kelas (PTK) merupakan bagian dari penelitian tindakan (action research) yang dilakukan oleh guru dikelas yang bertujuan memperbaiki dan meningkatkan kualitas dan kuantitas proses pembelajaran dikelas.

Harjodipuro (Elfanany, 2013: 21), mengartikan bahwa Penelitian Tindakan Kelas (PTK) adalah suatu pendekatan untuk memperbaiki pendidikan melalui perubahan dengan mendorong guru untuk memikirkan praktik mengajarnya sendiri, agar kritis terhadap praktik tersebut agar mau untuk mengubahnya.
Sedangkan McNiff (Arikunto, 2015:

191) memandang PTK sebagai bentuk penelitian reflektif yang dilakukan oleh pendidik sendiri terhadap kurikulum, pengembangan sekolah, meningkatkan prestasi belajar, pengembangan keahlian mengajar dan sebagainya.

Dalam penelitian ini peneliti mengumpulkan data dengan cara sebagai berikut:

a. Tes

Menurut Poerwanti dkk (Ain, 2013: 62), tes dapat diartikan sebagai himpunan pertanyaan untuk dijawab, pernyataan-pernyataan perlu dipilih, atau tugas-tugas peserta, tes digunakan untuk mengukur aspek tertentu. Tes digunakan mengukur kemampuan siswa dan mendapatkan data pencapaian hasil belajar saat pembelajaran. Tes diberikan kepada siswa secara individu maupun kelompok untuk mengetahui kemampuan kognitif, dilaksanakan pada pembelajaran tiap siklus.

Metode tes digunakan untuk mengukur hasil belajar yang telah dicapai siswa kelas Va SDN 001 Salo dalam belajar IPA pada materi peristiwa alam.

b. Observasi

Dalam menggunakan metode observasi, cara yang paling efektif adalah melengkapinya dengan format pengamatan sebagai instrumen. Format yang disusun berisi item-item tentang kejadian atau tingkah laku yang menggambarkan kejadian yang akan terjadi (Elfanany, 2013: 90)

Observasi dalam penelitian digunakan untuk menggambarkan aktivitas siswa dan guru dalam proses pembelajaran menggunakan pendekatan CTL (Contextual Teaching and Learning).

c. Dokumentasi

Syamsuddin dan Damaianti (Ain, 2013: 63) menyatakan Dokumentasi digunakan untuk mengumpulkan data berupadokumen 
atau rekaman. Dokumentasi dilakukan untuk memperkuat data observasi. Dokumen berupa foto , absensi, nilai siswa, kegiatan guru dan siswa dari lembar observasi, untuk memberikan gambaran secara konkret pelaksanaan kegiatan pembelajaran yang dilakukan dengan pendekatan CTL (Contextual Teaching and Learning).

\section{A. Instrumen penelitian}

Instrumen penelitian yang digunakan dalam penelitian ini adalah perangkat pembelajaran dan instrumen pengumpulan data.

\section{Perangkat Pembelajaran}

Perangkat pembelajaran yang digunakan dalam penelitian ini adalah sebagai berikut :

a. Silabus

Silabus merupakan acuan pengembangan RPP yang memuat identitas mata pelajaran, standar kompetensi, kompetensi dasar, materi pembelajaran, kegiatan pembelajaran, indikator pencapaian kompetensi, penilaian, alokasi waktu dan sumber belajar.

b. Rencana Pelaksanaan

Pembelajaran (RPP)

RPP dijabarkan dari silabus untuk mengarahkan kegiatan belajar siswa dalam upaya mencapai kompetensi dasar. RPP disusun untuk setiap KD yang dapat dilaksanakan dalam satu kali pertemuan atau lebih, guru merancang RPP untuk setiap pertemuan yang disesuaikan dengan penjadwalan di satuan pendidikan.

c. Lembar Kerja Siswa (LKS)

Lembar kerja siswa adalah salah satu bentuk program yang berlandaskan atas tugas yang harus diselesaikan dan berfungsi sebagai alat untuk mengalihkan pengetahuan dan keterampilan. LKS berisikan kegiatan siswa atau petunjuk kerja yang harus dikerjakan oleh masing-masing siswa.

\section{Instrumen pengumpulan data}

Instrumen yang digunakan untuk pengumpulan data dalam penelitian ini adalah sebagai berikut :

a. Tes

Tes adalah serentetan pertanyaan atau latihan atau alat lain yang digunakan untuk mengukur keterampilan, pengetahuan intelegensi, kemampuan atau bakat yang dimiliki individu atau kelompok. Dalam penelitian ini peneliti menggunakan teknik penilaian tes tertulis dengan bentuk instrumen essay dan objektif.

Menurut Sudjana (2014: 35) essay atau uraian adalah pertanyaan yang menuntut siswa menjawabnya dalam bentuk menguraikan, menjelaskan, mendiskusikan, membandingkan, memberikan alasan dan bentuk lain yang sejenis sesuai dengan tuntutan pertanyaan dengan menggunakan kata-kata dan bahasa sendiri. sedangkan tes objektif merupakan pilihan ganda. Tes pilihan ganda meliputi 4 pilihan jawaban (a, b, c atau d) setiap item jawaban yang benar akan diberi nilai atau skor 1 , dan bila salah diberi skor 0 .

b. Lembar observasi aktifitas siswa Berupa lembar pengamatan aktivitas siswa selama mengikuti proses pembelajaran dengan pendekatan CTL (Contextual Teaching Learning).

c. Lembar observasi aktifitas guru Berupa lembar observasi aktivitas guru yang digunakan untuk melihat aktivitas yang dilakukan guru selama kegiatan belajar mengajar dengan pendekatan CTL (Contextual Teaching Learning). 


\section{B. Teknik Analisis Data}

\section{Analisis aktivitas guru}

Aktivitas guru yang dinilai berupa kesesuaian pelaksanaan kegiatan guru dengan RPP yang telah dirancang. Setelah data aktivitas guru terkumpul melalui observasi, data tersebut diolah dengan menggunakan rumus persentase, yaitu sebagai berikut :

$$
\mathrm{P}=\frac{\mathrm{F}}{\mathrm{N}} \mathrm{X} 100 \%
$$

Keterangan :

$\mathrm{F}=$ Frekuensi yang sedang dicari

persentasenya

$\mathrm{N}=$ Number of cases (jumlah

frekuensi/banyaknya individu) $\mathrm{P}$

$=$ Angka persentase

$100 \%=$ bilangan tetap (Nurafni,

2014: 24)

Dalam menentukan kriteria penilaian tentang hasil observasi aktivitas guru, maka dilakukan pengelompokan atas 5 kriteria penilaian yaitu sangat baik, baik, sedang, kurang dan sangat kurang. Pelaksanaan pembelajaran dikatakan berhasil apabila kriteria persentase penilaian aktivitas guru minimal baik. Adapun kriteria persentase tersebut yaitu sebagai berikut

Tabel $\quad 3.1 \quad$ Interval Aktivitas Guru

\begin{tabular}{|c|c|c|}
\hline No & Interval & Kategori \\
\hline 1. & $90-100$ & Sangat Baik \\
\hline 2. & $70-89$ & Baik \\
\hline 3. & $50-69$ & Sedang \\
\hline 4. & $30-49$ & Kurang \\
\hline 5. & $10-39$ & Sangat Kurang \\
\hline
\end{tabular}

(Nurafni, 2014: 24)

\section{Analisis aktivitas siswa}

Setelah data aktivitas siswa terkumpul melalui observasi, data tersebut diolah dengan menggunakan rumus persentase, yaitu sebagai berikut :

$$
\mathrm{P}=\frac{\mathrm{F}}{\mathrm{N}} X 100 \%
$$

Keterangan :
$\mathrm{F}=$ Frekuensi yang sedang dicari

persentasenya

$\mathrm{N}=$ Number of cases (jumlah

frekuensi/banyaknya individu)

$\mathrm{P}=$ Angka persentase

$100 \%=$ bilangan tetap (Nurafni, 2014: 24)

Dalam menentukan kriteria penilaian tentang hasil observasi aktivitas siswa, maka dilakukan pengelompokan atas 5 kriteria penilaian yaitu sangat baik, baik, sedang, kurang dan sangat kurang.. Adapun kriteria persentase tersebut yaitu sebagai berikut

\section{Tabel $\quad 3.2 \quad$ Interval} Aktivitas Siswa

\begin{tabular}{|c|c|c|}
\hline No & Interval & Kategori \\
\hline 1. & $\begin{array}{c}90- \\
100\end{array}$ & $\begin{array}{c}\text { Sangat } \\
\text { Baik }\end{array}$ \\
\hline 2. & $70-89$ & Baik \\
\hline 3. & $50-69$ & Sedang \\
\hline 4. & $30-49$ & Kurang \\
\hline 5. & $10-39$ & $\begin{array}{c}\text { Sangat } \\
\text { Kurang }\end{array}$ \\
\hline
\end{tabular}

(Nurafni, 2014: 24)

\section{Hasil belajar}

Penilaian ini dilaksanakan untuk mengetahui tingkat hasil belajar siswa, yang dilaksanakan pada setiap akhir siklus, adapun tes yang akan dilakukan berbentuk tes tertulis. Hasil belajar ketuntasan individu tersebut diolah dengan menggunakan rumus : Siswa X $100 \%$

KBSI = Jumlah Skor Yang Dicapai

Keterangan:

$$
\text { Skor Maxsimum }
$$

KBSI = Ketuntasan belajar siswa secara individu

Siswa dikatakan tuntas apabila nilainya sama dengan KKM atau lebih tinggi dari KKM yaitu 75 .

Menentukan ketuntasan klasikal rumus yang digunakan yaitu:

$\mathrm{KK}=$ Jumlah siswa yang tuntas $\mathrm{X}$ $100 \%$

Jumlah seluruh siswa 
Keterangan:

KK = Ketuntasan klasikal

Jika ketuntasan klasikal siswa telah mencapai $80 \%$ dari seluruh siswa, maka hasil belajar siswa secara klasikal telah tercapai dengan baik. Adapun kriteria penilaian hasil belajar siswa dalam proses pembelajaran IPA dapat dilihat pada tabel berikut :

Tabel 3.3

Interval Hasil Belajar

\begin{tabular}{|c|c|c|}
\hline No & Interval & Kategori \\
\hline 1. & $86-$ & Baik \\
& 100 & Sekali \\
\hline 2. & $71-85$ & Baik \\
\hline 3. & $56-70$ & Sedang \\
\hline 4. & $41-55$ & Kurang \\
\hline 5. & $<40$ & $\begin{array}{c}\text { Sangat } \\
\text { Kurang }\end{array}$ \\
\hline
\end{tabular}

(Nurafni, 2014: 25)

\section{HASIL PENELITIAN PEMBAHASAN}

DAN

\section{A. Deskripsi Pratindakan}

Peneliti menganalisis hasil observasi awal melalui hasil belajar siswa sebelum tindakan, dengan tujuan untuk mengetahui keberhasilan siswa dalam memahami materi peristiwa alam dalam pelajaran IPA. Hasil pratindakan digunakan sebagai perbandingan hasil belajar sebelum dan sesudah penerapan pendekatan CTL (Contextual Teaching and Learning) pada mata pelajaran IPA materi peristiwa alam kelas Va SDN 001 Salo.

\section{B. Deskripsi Hasil Tindakan Tiap Siklus}

Ketuntasan secara individu dan klasikal pada hasil test siklus I dapat dilihat pada tabel berikut ini:

Tabel 4.2 Hasil Test Siklus I

\begin{tabular}{|c|c|c|c|}
\hline No & Interval & Kategori & Siklus I \\
\hline 1 & $86-100$ & $\begin{array}{c}\text { Baik } \\
\text { sekali }\end{array}$ & $\begin{array}{c}15 \\
(57,69 \%)\end{array}$ \\
\hline 2 & $71-85$ & Baik & $5(19,23 \%)$ \\
\hline 3 & $56-70$ & Sedang & $5(19,23 \%)$ \\
\hline 4 & $41-55$ & Kurang & $1(3,85 \%)$ \\
\hline 5 & $<40$ & $\begin{array}{c}\text { Sangat } \\
\text { kurang }\end{array}$ & $0(0 \%)$ \\
\hline \multirow{7}{*}{} & $\begin{array}{c}\text { Rata- } \\
\text { rata }\end{array}$ & & 83,85 \\
\cline { 2 - 4 } & Katagori & & Baik \\
\cline { 2 - 4 } & $\begin{array}{c}\text { Siswa } \\
\text { yang } \\
\text { tuntas }\end{array}$ & & $73,08 \%$ \\
\cline { 2 - 4 } & $\begin{array}{c}\text { Siswa } \\
\text { yang } \\
\text { tidak } \\
\text { tuntas }\end{array}$ & & $26,92 \%$ \\
\cline { 2 - 4 } & $\begin{array}{c}\text { Jumlah } \\
\text { siswa }\end{array}$ & & \\
\hline
\end{tabular}

Hasil belajar IPA materi peristiwa alam siswa kelas Va SDN 001 Salo setelah siklus I berkategori baik dengan rata-rata 80 dan ketuntasan secara klasikal 73,08\%. Hasil belajar siklus I ini meningkat jika dibandingkan dengan skor awal.

\section{Hasil Test Siklus II}

Ketuntasan secara individu dan klasikal pada hasil test siklus II dapat dilihat pada tabel berikut ini:

Tabel 4.3 Hasil Test Siklus II

\begin{tabular}{|c|c|c|c|}
\hline No & Interval & Kategori & Siklus I \\
\hline 1 & $86-100$ & $\begin{array}{c}\text { Baik } \\
\text { sekali }\end{array}$ & $\begin{array}{c}19 \\
(73.08 \%)\end{array}$ \\
\hline 2 & $71-85$ & Baik & $5(19,23 \%)$ \\
\hline 3 & $56-70$ & Sedang & $2(7,69 \%)$ \\
\hline 4 & $41-55$ & Kurang & $0(0 \%)$ \\
\hline 5 & $<40$ & $\begin{array}{c}\text { Sangat } \\
\text { kurang }\end{array}$ & $0(0 \%)$ \\
\hline \multirow{7}{*}{} & $\begin{array}{c}\text { Rata- } \\
\text { rata }\end{array}$ & & 90.19 \\
\cline { 2 - 4 } & Katagori & & Baik Sekali \\
\cline { 2 - 4 }
\end{tabular}




\begin{tabular}{|c|c|c|}
\hline $\begin{array}{c}\text { Siswa } \\
\text { yang } \\
\text { tuntas }\end{array}$ & & $92,31 \%$ \\
\hline $\begin{array}{c}\text { Siswa } \\
\text { yang } \\
\text { tidak } \\
\text { tuntas }\end{array}$ & & $7,69 \%$ \\
\hline $\begin{array}{c}\text { Jumlah } \\
\text { siswa }\end{array}$ & & 26 iswa \\
\hline
\end{tabular}

Hasil belajar IPA siswa kelas Va SDN 001 Salo setelah siklus II berkategori baik sekali dengan rata-rata 90,19 dan ketuntasan secara klasikal 92,31\%. Hasil belajar siklus II ini meningkat jika dibandingkan dengan skor awal dan siklus

\section{Perbandingan Hasil Tindakan Tiap Siklus}

Data yang dianalisis dalam penelitian ini adalah hasil belajar siswa pada materi peristiwa alam dengan penerapan pendekatan CTL (Contextual Teaching and Learning).

\section{Hasil Belajar Siswa} Untuk mengetahui perkembangan hasil belajar siswa dari siklus I dan II dengan penerapan pendekatan CTL (Contextual Teaching and Learning) pada siswa kelas Va SD Negri 001 Salo dapat dilakukan analisis terdiri dari hasil belajar individu dan hasil belajar secara klasikal

\section{a. Hasil Belajar Secara Individu}

Berdasarkan data skor awal dan soal evaluasi siklus I dan siklus II,

Dapat disimpulkan bahwa hasil belajar siswa sesudah tindakan meningkat. Kategori hasil belajar pada siklus I yaitu siswa mendapat nilai dengan kategori baik sekali yaitu 15 orang, yang mendapat nilai kategori baik yaitu 5 orang, dan yang mendapat nilai sedang yaitu
5 orang siswa, sedangkan 1 orang lagi mendapat nilai dengan kategori kurang.

Kategori hasil belajar yang diperoleh siswa pada siklus II juga terjadi peningkatan setelah diterapkan pendekatan CTL (Contextual Teaching and Learning), siswa yang mendapatkan kategori baik sekali yaitu 19 orang, siswa yang mendapat kategori baik 5 orang dan siswa yang mendapat kategori sedang 2 orang. Rata- rata skor awal siswa 69,04 meningkat pada siklus I yaitu 83,85 dan siklus II 90,19. Peningkatan nilai rata-rata dari siklus I ke siklus II yaitu sebesar 6,34.

b. Ketuntasan Belajar Klasikal

Hasil analisis ketuntasan belajar siswa secara klasikal pada siklus I dan siklus II pada materi peristiwa alam setelah penerapan pendekatan CTL (Contextual Teaching and Learning) di kelas Va SDN 001Salo

\section{SIMPULAN}

1. Perencanaan Pembelajaran IPA Materi Peristiwa Alam

Dalam tahap perencanaan tindakan pada siklus I dan siklus II peneliti menyusun silabus dan rencana pelaksanaan pembelajaran berdasarkan langkah-langkah

pendekatan CTL (Contextual Teaching and Learning), mempersiapkan bahan ajar berupa gambar, vidio, power point, alat peraga, menyiapkan format pengamatan atau lembar observasi aktivitas guru dan aktivitas yang dilakukan oleh siswa dan mempersiapkan soal evaluasi dan LKS (Lembar Kerja Siswa) yang sesuai dengan materi yang dipelajari.

2. Proses Pembelajaran IPA Materi Peristiwa Alam 
Proses pembelajaran yang dilaksanakan guru dengan pendekatan CTL (Contextual Teaching and Learning) pada siklus I secara keseluruhan telah dilaksanakan hampir sesuai dengan RPP, karna perlu pengkondisian kelas secara maksimal, dalam kegiatan bertanya atau questioning belum terlaksana, karena kurang adanya respon dari siswa. Siklus II secara keseluruhan proses pembelajaran terlaksana guru dengan baik, karena guru telah melaksanakannya sesuai dengan RPP, selain itu guru telah memberikan bimbingan dan motivasi agar siswa lebih aktif dan percaya diri. Sedangkan aktivitas siswa pada siklus I belum berjalan secara kondusif, kemampuan siswa untuk berani bertanya masih kurang, tanggung jawab dalam kelompok masih memerlukan bimbingan agar dapat dimaksimalkan. Siklus II kemampuan siswa untuk bertanya sudah meningkat, siswa berani untuk bertanya jika tidak mengerti dalam materi yang disampaikan serta siswa mampu bekerjasama dengan kelompok dengan baik.

3. Hasil Pembelajaran IPA materi Peristiwa Alam

Berdasarkan hasil

pembelajaran permasalahan social yang telah dijabarkan pada bab IV, diketahui bahwa ketuntasan sebelum tindakan hanya mencapai $38,46 \%$ atau hanya 10 orang siswa yang tuntas. Pada siklus I meningkat menjadi 73,08\% Atau hanya 19 orang siswa yang tuntas, dan siklus II meningkat lagi menjadi 92,31\% Atau 24 Orang Siswa Yang Tuntas.

\section{DAFTAR PUSTAKA}

Ain, Anisa Huril. 2013. Peningkatan Kualitas Pembelajaran Ipa Melalui Penerapan Pendekatan Ctl Pada Siswa Kelas Vc Sdn Purwoyoso 03 Semarang. Universitas Negeri
Semarang. Semarang: Tidak Dipublikasikan. Pdf. 29 Januari.

Arikunto, S. dkk. 2015. Penelitian Tindakan Kelas. Jakarta: Bumi Askara.

Efi. 2015. Upaya Meningkatkan Hasil Belajar IPA Pada Konsep Perkembangbiakan Tumbuhan Melalui Pendekatan Kontekstual. Universitas Islam Negeri Syarif Hidayatullah. Jakarta: Tidak Dipublikasikan. Pdf. 29 Januari.

Elfanany, B. 2013. Penelitian Tindakan Kelas. Yogyakarta: Araska.

Hartini, Nanik. 2010. Penerapan Model Pembelajaran CTL Untuk Motivasi Belajar IPA Kelas II Sekolah Dasar Negeri 02 Gambir Manis Kecamatan Pracimantoro

Kabupaten Wonogiri. Fakultas Keguruan dan Ilmu Pendidikan Universitas Sebelas Maret. Surakarta: Tidak Dipublikasikan. Pdf. 29 Januari.

Johnson, EB. 2014. Contextual Taeching and Learning: Menjadikan Kegiatan Belajar- Mengajar Mengasyikkan dan Bermakna. Bandung: Kaifa.

Jufri, W. 2013. Belajar dan Pembelajaran Sains. Bandung: Pustaka Reka Cipta.

Moogangga, H. 2013. Jurnal Meningkatkan Hasil Belajar Siswa Materi Sifat Cahaya Melalui Pendekatan Kontekstual Berbasis Diskusi Kelompok Kelas V Sdn 3 Momalia Kecamatan Posigadan Kabupaten Bolaang Mongondow Selatan. Pdf. 29 Januari.

Nurafni. 2014. Penerapan Metode Cotextual Taeching and Learning (Ctl) Untuk Meningkatkan Hasil Belajar Siswa Mata Pelajaran IPA 
Dikelas IV SDN 010 Siabu Kampar. STKIP Pahlawan Tuanku Tambusai Bangkinang. Bangkinang: Tidak Dipublikasikan.

Purwanto, MN. 2010. Psikologi Pendidikan. Bandung: PT Remaja Rosdakarya.

Rusman. 2014. Model- Model Pembelajaran: Mengembangkan Profesionalisme Guru. Jakarta: Rajawali Pers.

Sudjana, Nana. 2014. Penilaian Hasil Proses Belajar Mengajar. Bandung: Rosda Karya

Taufik, T. 2009. Mozaik Pembelajaran Inovatif. Jakarta: Kencana Prenada Group.

Thobroni. 2015. Belajar dan Pembelajaran: Teori dan Praktik. Yogyakarta: ArRuzz Media.

Wisudawati, AW dan Sulistyowati. 2014. Metodologi Pembelajaran IPA. Jakarta: Bumi Askara. 